\title{
Armillaria Population in Flood-Plain Forest of Natural Pedunculate Oak Showing Oak Decline
}

\author{
Wojciech Szewczyk, Hanna Kwaśna*, Jolanta Behnke-Borowczyk \\ Department of Forest Pathology, Faculty of Forestry, Poznań University of Life Sciences, \\ Wojska Polskiego 71c, 60-625 Poznań, Poland
}

Received: 15 May 2015

Accepted: 9 January 2016

\begin{abstract}
We studied the Armillaria population in a forest of natural pedunculate oak subject to periodic flooding and showing symptoms of oak decline. The study area was in Wołów Forest District in the Oder River Valley flood plain. Armillaria DNA was isolated by direct extraction from rhizomorphs and mycelium in soil and root samples. Armillaria species were identified by PCR-RFLP of IGS-1 rDNA using the restriction enzymes $A l u \mathrm{I}, T a q \mathrm{I}, M s p \mathrm{I}$, and Bsm I. Rhizomorphs were found in 10 out of 12 sites. The number of soil rhizomorphs collected (0-28 in $100 \mathrm{~kg}$ of soil per sampling site) often differed significantly between sites. The mean number of soil rhizomorphs per sample was significantly less in flooded sites $(0.30$ or 0.46$)$ than in the non-flooded control (1.16), and insignificantly less in sites flooded once (0.30) than in sites flooded twice (0.46). Comparison of the RFLP patterns for Armillaria samples from the oak forest with those for Armillaria testers showed them to be A. borealis (two DNA samples), A. cepistipes (seven samples), A. gallica (150 samples), and A. solidipes (one sample). RFLP patterns for Taq 1 were unfamiliar, since this enzyme has rarely been used, while $A$. cepistipes gave a rare pattern with $A l u \mathrm{I}$, known previously only from Japanese isolates of this fungus. Since $A l u \mathrm{I}$ and $T a q \mathrm{I}$ each produced a similar pattern for A. borealis and A. solidipes, an additional functionally efficient enzyme, $B s m \mathrm{I}$, was used. These results and those from other Armillaria population studies showed that flooding affected the abundance of soil rhizomorphs, but not the diversity of Armillaria species. The decreased abundance of Armillaria rhizomorphs in soil subjected to flooding may be indicative of the flooded soil syndrome in which general loss of fungi occurs. Flooding may still be considered, however, to be a short-term inciter and stress inducer, occurring between "primary" factors and "secondary" agents that predispose the tree to infection. This is the first report on populations of Armillaria in declining oaks in flood-plain forests in the northern hemisphere.
\end{abstract}

Keywords: Armillaria gallica, flood plain, ITS-1 rDNA, pedunculate oak, RFLP, stress

*e-mail: kwasna@up.poznan.pl 


\section{Introduction}

Pedunculate oak (Quercus robur L.) is the most valuable forest-forming deciduous tree species in Poland in terms of economic and ecological value. It accounts for approximately $7 \%$ (630,000 hectares) of total forest area [1]. The health of oak stands has decreased recently and mass oak decline has been observed throughout Poland [2]. Frost damage, which leads to xylem embolism, in combination with periods of drought, is regarded as the driving force leading to crown dieback in hardwoods. In oak decline the emphasis is put on the occurrence of drought before disease onset or on enhancement of disease progress. As a consequence of lower vitality, oak stands are susceptible to soil-borne pathogens (e.g., Phytophthora, especially P. quercina T. Jung and Armillaria) and insects (Agrilus) [3]. Long-term oak decline is imminent, with implications for the future status of oak forests in Europe [4].

In Wołów Forest District the most valuable and important stands, including pedunculate oak, grow in the Oder River Valley. Oak, with an admixture of other broadleaved tree species, occupies 66,429 ha $(13.3 \%$ of the forest area) in the valley. Considering its high requirement for water (the mean daily water consumption of a $33 \mathrm{~m}$ oak is $174-460 \mathrm{~kg}$ /day), pedunculate oak generally prefers moist conditions created by rivers. Recently, however, trees have shown symptoms of oak decline. Many of the most valuable stands are in the flood plain of alluvial, moist lowland forests that they are flood-dependent ecosystems. Plants in these forests rely on well-timed periodic floods for regeneration of sites. The Oder River flood plain forests are listed in Annexe I of the European Habitats Directive as among "Europe's most threatened natural ecosystems" and as being a "priority forest habitat type" [5].

Very high precipitation (300-600 $\mathrm{mm}$ over a few days) caused the Oder River to flood in June-July 1997. It was the most disastrous flood in the history of Poland. Flooding was very rapid; water levels rose by up to $4 \mathrm{~m}$ in half a day and remained stagnant for three months. More than 13,300 ha of forests, including more than 2,000 ha in Wołów Forest District, were flooded. The next flood in this region occurred in May 2010. Although shorter, it was more severe than the previous one. In Wołów Forest District, however, water stayed for only one month. Although forest sites in the flooded area were not eroded, stagnant water increased anaerobic processes in the soils.

Flooding affects most plants. Excessive soil moisture usually decreases oxygen levels. This impedes respiration and releases energy from sugars, and in anaerobic conditions favours the formation of carbon dioxide, toxic ethanol, methane, nitrogenous gases, and hydrogen sulphide. Ultimately, the roots can suffocate and die. Rapid flushes of water can also wash away the surrounding soil, increasing exposure of roots to the air. Even after the flood waters recede, the damaged plants are more vulnerable to other stressors such as wind, which may cause uprooting. Plants suffering from excess-water stress are more susceptible to infection by phytopathogens, including fungi. Also, excessively wet soil tends to favour the growth of soil-microorganisms, including soil-borne and root-rot pathogens. Symptoms of infection and damage often appear after many months or years.

It was hypothesized that the two flood events contributed to the oak decline in Wołów Forest District. These could be the "primary" stress factor that increased tree susceptibility to the root pathogens Phytophthora and Armillaria.

Armillaria root rot is one of the most dangerous tree diseases in the northern hemisphere [6-8]. In Poland in 2012 the pathogen was found to occur with high incidence across 99,215 ha [2]. At present, more than 40 species of Armillaria have been described. Seven species, including $A$. borealis Marxm. et Korhonen, A. cepistipes Velen, A. ectypa (Fr.) Lamoure, A. gallica Marxm., A. mellea (Vahl: Fr.) Kumm., A. solidipes (Peck), and A. tabescens (Scop.: Fr.) Emel. occur in Europe. Only A. ectypa has not been reported from Poland [7].

Armillaria solidipes is considered to be the main pathogen in coniferous stands in Europe. It causes particularly high losses in Poland [2, 7-9]. It dominates in fresh mixed coniferous forest, particularly on younger trees. It may, however, also colonize deciduous species, including oak, beech, and birch. The relative importance of $A$. solidipes increases when conifers replace hardwoods [2, 6].

Two species of Armillaria; A. gallica and A. cepistipes may colonize deciduous trees and its wood. In Poland, the former is frequently reported on Quercus, particularly on stressed trees including large-sized specimens, often in areas with disturbed water relations [10]. Armillaria cepistipes has been found on old oaks, beech trees, and dead willow wood. It also colonizes coniferous species and in Poland was detected in older Norway spruce and fir stands, occurring in most forest site types [10]. Both species are considered to be weak pathogens [11].

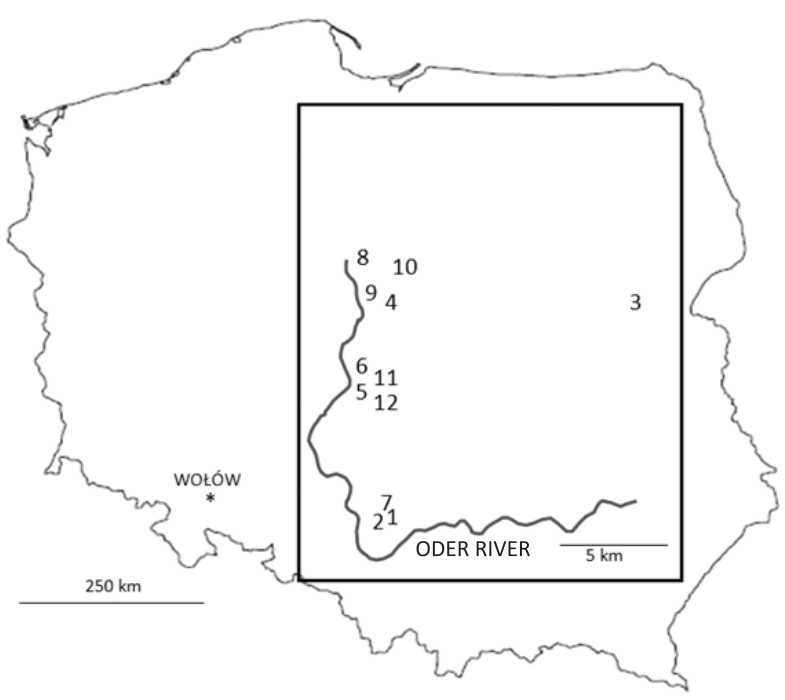

Fig. 1. Map of Poland with sites surveyed in Wołów Forest District. 
Armillaria gallica is the species that produces the greatest number of rhizomorphs. Armillaria cepistipes also produces thick, strong, and intensively branched rhizomorphs [11]. Rhizomorphs form a dense network in the upper layers of forest soils and easily reach and colonize wood.

There is a lack of data on Armillaria occurring in oak stands in flood plains. The aims of this research were to document species of Armillaria present in flood-plain oak stands in Wołów as well as to determine distribution and relative abundance of Armillaria in an attempt to elucidate factors contributing to the oak decline observed in the Oder River Valley. Armillaria species were identified by analysis of conserved regions of the ribosomal RNA gene (rDNA), i.e. IGS-1 rDNA.

\section{Materials and Methods}

\section{Site Description, Experimental Design, and Sampling of Roots}

The study was made in 12 sites $(11+$ control $)$ in flood-plain forest of natural pedunculate oak in Wołów Forest District, located in the Oder River Valley, Lower Silesia, Poland (51 $\left.34^{\prime} 13^{\prime \prime} N 16^{\circ} 62^{\prime} 83^{\prime \prime} E\right)$ in 2011-13 (Fig. 1). Admixture species in the surveyed sites included sessile oak (Quercus petraea (Matt.) Liebl.) (40\%), common alder (Alnus glutinosa Gaertn.) (20\%), small-leaved lime (Tilia cordata Mill.) (10-20\%), and silver birch (Betula pendula Roth.) (10\%). Sites were located 270-1,700 $\mathrm{m}$ from the river. Sites $1,2,5,6,7,11$, and 12 were subjected to periodic flooding for three months in 1997 and one month in 2010. Sites 4, 8, 9, and 10 were subjected to flooding for three months in 1997. Site 3 was the control area not subjected to flooding and located $12 \mathrm{~km}$ away on lessive, arable soils of very good quality (class II). Lower Silesia is a very good area for plant production because of its mild winters, warm summers, and long growing season (average 226 days). The mean annual precipitation is low $(612 \mathrm{~mm})$ and the mean annual temperature is relatively high $\left(8.2^{\circ} \mathrm{C}\right)$ (data from the period 2000-10). All surveyed sites had the same site type (flood-plain forest), soil type (alluvial), and broadly similar age of trees (45-) 50-100 years. The study was made in managed stands that had been thinned in 1990.

In summer 2013, samples of soil $(25 \times 25 \times 25 \mathrm{~cm}=$ $4 \mathrm{~kg}$ ) were collected from the layer $0-25 \mathrm{~cm}$ deep at six evenly distributed locations in each of four $1,000 \mathrm{~m}^{2}$ plots in an area of 1 ha at each site. Soil was sieved through a $1 \mathrm{~cm}$ mesh for collection of rhizomorphs. Three oak trees within the 1 ha area at each site were randomly selected for further sampling of roots. All trees showed moderate symptoms of oak dieback including smaller, pale green or yellow leaves, increased defoliation, and death of fine twigs, followed by death of small and large branches. In August 2013, roots of oaks were carefully excavated from a soil-profile pit and roots with Armillaria rhizomorphs or mycelium (if present) were collected from a depth of 0.5-1 m.

\section{Isolates, DNA Extraction, PCR Amplification, and RFLP Analysis}

One-hundred and sixty samples of Armillaria rhizomorphs from soil (139 samples) and roots (7 samples), and mycelium from roots (14 samples) were collected from 10 sites. No rhizomorphs or mycelium were found at sites 6 or 9. Rhizomorphs and mycelium were frozen, lyophilized, and ground in liquid nitrogen. DNA was extracted with the Bead-Beat Micro Gravity Kit (A \& A Biotechnology) from $10 \mathrm{mg}$ samples of powdered mycelium. DNA extracts were diluted 10-fold with sterile distilled water to be used as a template for the polymerase chain reaction. In addition, haploid tester isolates (A. borealis, A. cepistipes, A. gallica, A. mellea, and $A$. solidipes) were used for comparative analyses. They were grown in $2 \%$ malt extract broth (MEB; Difco malt extract $\left.20 \mathrm{~g} \mathrm{l}^{-1}\right)$ at $24^{\circ} \mathrm{C}$ for three weeks in darkness. The mycelium was harvested with a strainer, lyophilized, and ground to a fine powder, and DNA was extracted. The IGS-1 rDNA (between the 3' end of the LSU 28S rDNA and the 5 ' end of the $5 \mathrm{~S}$ gene) was amplified with PCR primer pairs 5SA (5' CAGAGTCCTATGGCCGTGGAT 3') and CNL12 (5' CTGAACGCCTCTAAGTCAG 3') $[37,38]$. Each $25 \mu \mathrm{l}$ PCR mixture included $0.2 \mu \mathrm{M}$ of each primer, $2 \times$ PCR MixPlus (Taq DNA polymerase

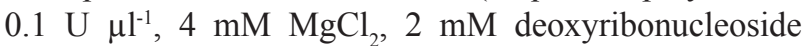
triphosphates (dNTPs)) and 100 ng of DNA (A\&A Biotechnology, Poland). PCR included an initial denaturation step at $94^{\circ} \mathrm{C}$ for 5 min followed by 30 cycles of $94^{\circ} \mathrm{C}$ for $30 \mathrm{~s}, 42^{\circ} \mathrm{C}$ for $1 \mathrm{~min}$, and $72^{\circ} \mathrm{C}$ for $2 \mathrm{~min}$, final extension at $72^{\circ} \mathrm{C}$ for $10 \mathrm{~min}$, and then cooling at $4^{\circ} \mathrm{C}$. Amplification was carried out in a T3 thermocycler (Biometra, GmbH, Göttingen, Germany). The amplified regions included $800-880 \mathrm{bp}$. The amplified products of the IGS1 region were subjected to RFLP analysis using restriction enzymes AluI, TaqI, MspI, and BsmI (MBI Fermentas, St. Leon-Rot, Germany). The PCR reaction mix $(18 \mu \mathrm{l})$ was subjected to digestion by $10 \mathrm{U}$ of enzyme for $12 \mathrm{~h}$ at $37^{\circ} \mathrm{C}(A l u \mathrm{I}, M s p \mathrm{I}$ or $B s m \mathrm{I})$ or $6 \mathrm{~h}$ at $65^{\circ} \mathrm{C}(\mathrm{Taq} \mathrm{I})$. The products were electrophoresed in gels $(2 \%$ NuSieve agarose, Cambrex, BioScience, Wokingham, UK $+1 \%$ standard agarose) in $1 \mathrm{x}$ TBE and stained with ethidium bromide at $0.5 \mu \mathrm{g} \mathrm{ml}^{-1}$. Restriction digestion patterns were compared for each enzyme. DNA band sizes were determined by comparison with bands of a $\varphi \chi 174$ DNA HaeIII digest and the Low DNA Mass Ladder (Invitrogen Ltd., Paisley, UK) using GeneTools gel analysis Software (Syngene). Fragments smaller than $100 \mathrm{bp}$ were not scored because they could not be distinguished from primer dimers. Two fragments with difference $<10 \mathrm{bp}$ were considered identical. The amplified fragments of IGS-1 rDNA of Armillaria testers were purified using Clean-Up Kit (A \& A Biotechnology, Gdańsk, Poland), amplified with 5SA and CNL12 primers, and sequenced at the DNA Research Centre (Poznań, Poland) using the BigDye1 Terminator 


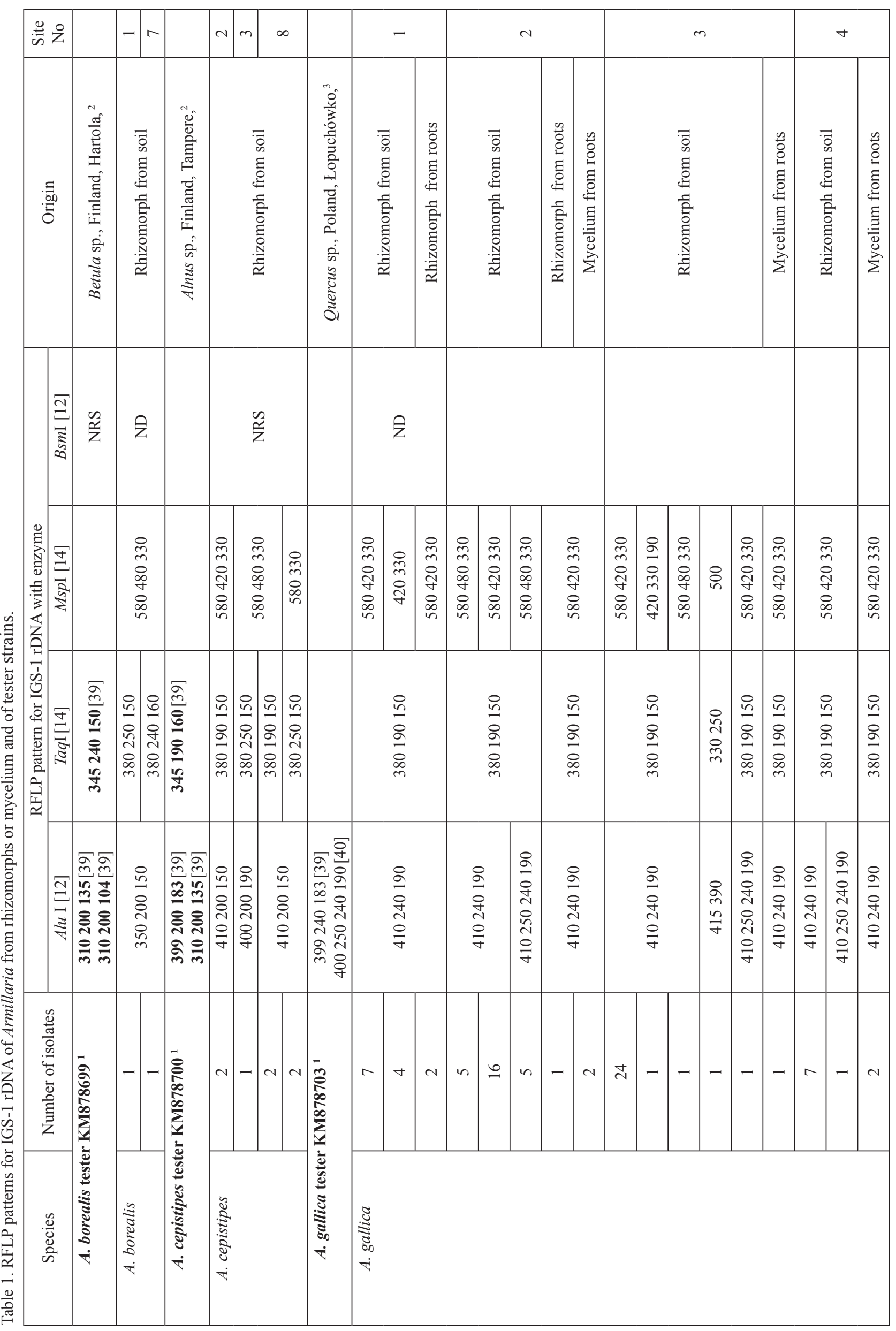




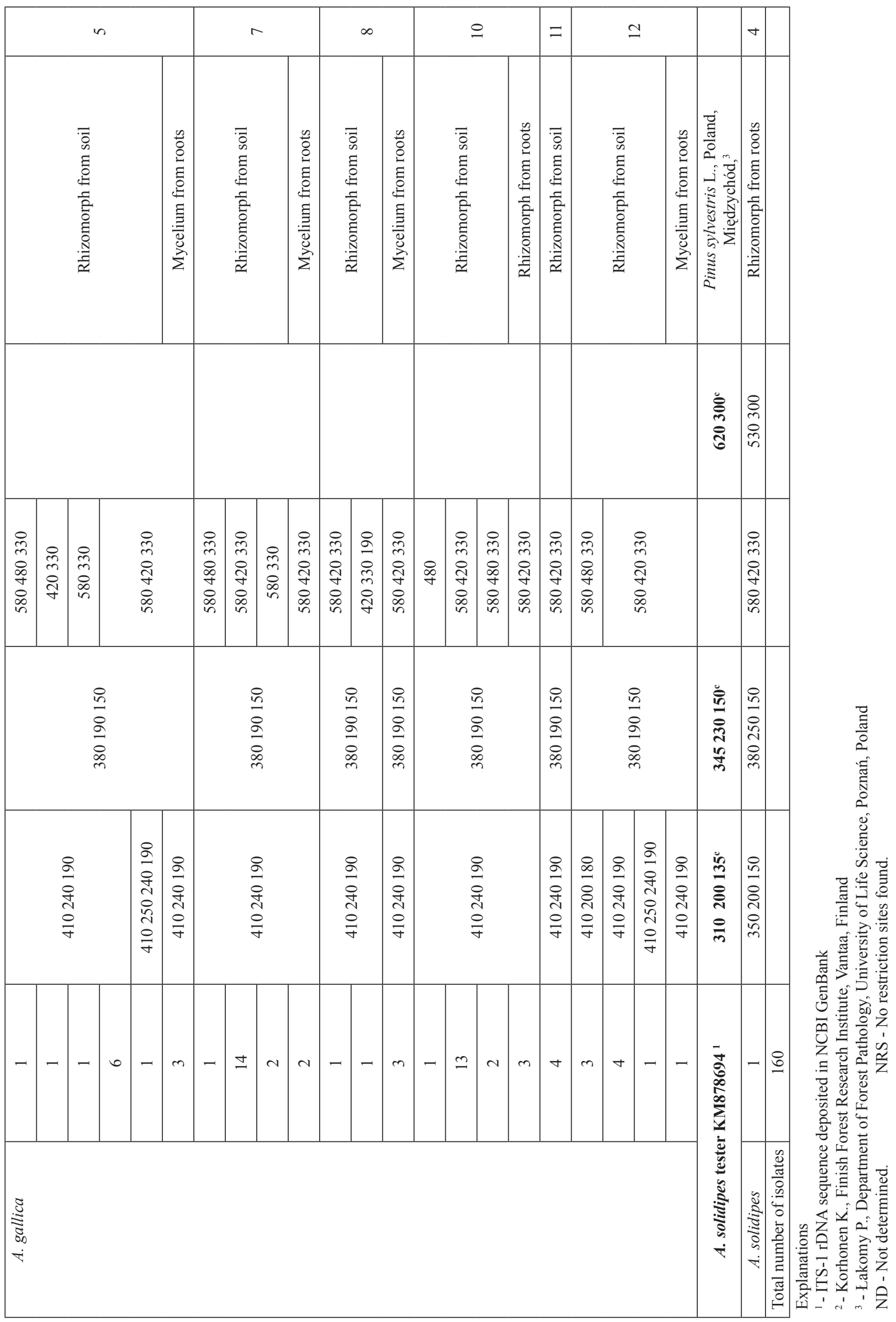


v 3.1 Cycle Sequencing Kit (AB Applied Biosystems, Foster City, CA, USA) and ABI PRISM 3100 Genetic Analyzer (Applied Biosystems, Foster City, USA). Sequences were queried against the GenBank database using BLAST. Sequences of IGS-1 rDNA of Armillaria testers were deposited in NCBI GenBank (Table 1).

\section{Assessment of Tree Defoliation}

In August 2011, 2012, and 2013, defoliation of each sampled oak tree was assessed according to Borecki and Keczyński [12]. The degree of defoliation was classified according to the European classification [13]. Mean defoliation in three years was calculated.

\section{Statistical Analysis}

The statistical significance of difference between the numbers of Armillaria rhizomorphs detected in sites flooded twice (in 1997 and 2010) and once (in 1997) was determined by Chi-squared $\left(\chi^{2}\right)$ test. The coefficients of genetic similarity $(\mathrm{S})$ between the DNA samples studied (from rhizomorphs or mycelium) and between DNA samples and testers were calculated using the formula of Nei and $\mathrm{Li}[14]$ :

$$
\mathrm{S}_{\mathrm{ij}}=2 \mathrm{~N}_{\mathrm{ij}} /\left(\mathrm{N}_{\mathrm{i}}+\mathrm{N}_{\mathrm{j}}\right)
$$

...where $\mathrm{N}_{\mathrm{ij}}=$ the number of shared alleles for two ( $i$-th and $j$-th) DNA samples, $\mathrm{N}_{\mathrm{i}}=$ the number of alleles present in the $i$-th sample, and $\mathrm{N}_{\mathrm{j}}=$ the number of alleles present in the $j$-th sample. The data were scored and entered in a computer as binary matrices where 0 coded for the absence and 1 for the presence of a band formed by RFLP of IGS-1 rDNA. The principal component and the average linkage cluster analyses were performed using the statistical package GenStat v. 7.1.

The relationship between the number of rhizomorphs in soil and mean tree defoliation in 2011-13 and distance $(\mathrm{m})$ from the river was estimated using Pearson's correlation coefficient.

\section{Results}

Armillaria rhizomorphs were detected in 10 out of 12 sites (Table 2). There were often significant differences between flooded sites in the number of soil rhizomorphs collected, which ranged between 0 and 28 . There were significantly fewer soil rhizomorphs per sample in flooded sites $(0.30$ or 0.46$)$ than in the non-flooded control (1.16), and non-significantly fewer in sites flooded once $(0.30)$ than in sites flooded twice (0.46). Rhizomorphs and mycelium were also detected on the sampled roots (Table 1). There was moderate positive correlation between the number of rhizomorphs in soil and distance from the river ( $r=0.630$ at $P \leq 0.001)$.

The IGS-1 rDNA was successfully amplified directly from all samples of Armillaria rhizomorphs and mycelium using primers 5SA and CNL12 with the method described for amplification from freeze-dried mycelium. For 160 isolates, PCR amplification of the IGS-1 rDNA yielded single strong bands of 600-650 bp. RFLP patterns of IGS-1 rDNA with $A l u \mathrm{I}, T a q \mathrm{I}, M s p \mathrm{I}$, and BsmI yielded 2-4 fragments of rDNA (Table 1). Testers of $A$. borealis, A. cepistipes, A. gallica, and A. solidipes gave AluI, TaqI, MspI, and BsmI patterns typical for the particular species [15-17]. Comparison of patterns for the rhizomorph/ mycelium samples with patterns for testers showed that A. borealis (two samples), A. cepistipes (seven samples), A. gallica (150 samples), and $A$. solidipes (one sample) were present (Table 1). Patterns for the rhizomorph/ mycelium samples and the testers often differed indistinctly because of small differences in the number of nucleotides (10-15 bp) in the particular region. Inclusion of all these small differences in the statistical analyses was the main reason for low values of genetic similarity coefficients (S) between two isolates of the same species (Table 3). AluI, TaqI, and MspI each produced two patterns for A. cepistipes. AluI produced four patterns, TaqI two patterns, and MspI seven patterns for A. gallica.

The mean defoliation in 2011-13 of the trees sampled was between $15 \%$ and $46 \%$ (Table 2 ). There was moderate positive correlation between the number of rhizomorphs

Table 2. Number of the soil Armillaria rhizomorphs and mean defoliation of the sampled trees (2011-2013) at 12 sites that were flooded twice (1997 and 2010), once (1997) or not flooded.

\begin{tabular}{|c|c|c|c|c|c|c|c|c|c|c|c|c|}
\hline & \multicolumn{12}{|c|}{ Site number } \\
\hline & 1 & 2 & 5 & 6 & 7 & 11 & 12 & 4 & 8 & 9 & 10 & 3 \\
\hline & \multicolumn{7}{|c|}{ Flooded twice } & \multicolumn{4}{|c|}{ Flooded once } & $\begin{array}{l}\text { Not } \\
\text { flooded }\end{array}$ \\
\hline $\begin{array}{l}\text { No. rhizomorphs } \\
\text { per } 100 \mathrm{~kg} \text { soil* }\end{array}$ & $12^{\mathrm{a}, \mathrm{c}}$ & $28^{\mathrm{a}, \mathrm{b}, \mathrm{d}, \mathrm{e}, \mathrm{f}}$ & $10^{\mathrm{b}}$ & $0^{\mathrm{c}, \mathrm{d}, \mathrm{g}, \mathrm{i}}$ & $18^{\mathrm{e}, \mathrm{g}, \mathrm{h}, \mathrm{j}}$ & $4^{\mathrm{f}, \mathrm{h}}$ & $8^{i, j}$ & 8 & $6^{\mathrm{k}}$ & $0^{1}$ & $16^{\mathrm{k}, \mathrm{l}}$ & 29 \\
\hline No. rhizomorphs per sample & 0.48 & 1.12 & 0.4 & 0 & 0.72 & 0.16 & 0.32 & 0.32 & 0.24 & 0 & 0.64 & 1.16 \\
\hline Mean no. isolates per sample* & \multicolumn{7}{|c|}{$0.46^{\mathrm{a}}$} & \multicolumn{4}{|c|}{$0.30^{\mathrm{b}}$} & $1.16^{\mathrm{a}}{ }^{\mathrm{b}}$ \\
\hline Mean tree defoliation & 24 & 37 & 24 & 15 & 46 & 41 & 28 & 21 & 30 & 20 & 30 & 42 \\
\hline
\end{tabular}

*The same letter in a row shows statistically significant difference between number of rhizomorphs or isolates according to $\chi^{2}$ tests at $P=0.05$ and $P=0.001$. 
Table 3. Coefficients of genetic similarity (S) of RFLP patterns between DNA from rhizomorph/mycelium samples and testers.

\begin{tabular}{|c|c|c|c|c|}
\hline Pairing & Alu $\mathrm{I}$ & Taq & Msp I & Bsm $\mathrm{I}$ \\
\hline A. borealis with A. borealis tester & 0.3333 & $0.3333,0.6666$ & & \\
\hline A. cepistipes with A. cepistipes tester & $0.3333,0.6666$ & $0,0.3333$ & & \\
\hline A. gallica with A. gallica tester & $0,0.3333,0.5714$ & & & 0.8000 \\
\hline A. solidipes with A. solidipes tester & 0.3333 & 0.3333 & & \\
\hline A. borealis with A. borealis & 1.0 & 0.3333 & $0.6666,0.8000$ & \\
\hline A. cepistipes with A. cepistipes & $0.3333,1.0$ & & & \\
\hline A. gallica with A. gallica & $0,0.2857,0.3333,1.0$ & & & \\
\hline
\end{tabular}

in soil and mean tree defoliation in $2011-13(r=0.656$ at $P \leq 0.001)$.

\section{Discussion}

The "host-stress-saprogen concept model for forest dieback-decline diseases" of Houston [18] considers decline to be disease caused by successive action of stress factors followed by organisms of secondary action (saprogens), which can only successfully attack the weakened hosts. The model is based on the generally accepted theory of stress-induced predisposition of trees to pathogen/pest attack.

Abiotic and biotic stress factors affected the vitality of natural oaks in the Oder River Valley. Damage caused by animals (browsing), insects (defoliation), fungi (necrosis caused by Erysiphe alphitoides Griffon \& Maublanc), drought, and the sun's radiation (discoloration) were common $[19,20]$. Periodic flooding along the river usually resulted from heavy rain or melting snow, which caused the river to overflow its banks. Flooding may be included in the "drought" category because, by interfering with water uptake in oxygen-deprived roots, it causes "physiological drought." These were the "primary" stress factors. They had an effect at the beginning of the causative chain of the observed oak decline process. The "secondary" factors, including organisms as contributing agents, operate at the end of the causative chain.

In Houston's examples, oaks with the decline syndrome were often infected by species of Armillaria [18]. Different species of Armillaria in different situations can be "secondary" agents. Armillaria gallica has been the species most often detected on oak in the northern hemisphere. This species was associated with oak decline in Austria, France, Italy, and Poland, and with widespread mortality of oaks in Arkansas and Missouri, USA, in mixed hardwood forests in California, USA, and also of conifers in southern Ontario, Canada [21-26].

Four species of Armillaria were identified in floodplain oak forests in the present study. Armillaria gallica was the most common ( $94 \%$ of rhizomorphs/mycelia). It was accompanied by $A$. cepistipes (4\%), A. borealis (1\%), and A. solidipes (1\%). The Armillaria population observed in the Oder River Valley was similar to that observed in stressed oaks, which were often diseased and sometimes dead in non-flooded forest in central-west Poland in 1998 [21]. The most common species there was also $A$. gallica, which was accompanied, as in the present study, by $A$. solidipes (7\% of isolates) and A. cepistipes ( $3 \%$ of isolates).

Increased soil moisture has been associated with increased severity of Armillaria root rot in oak, chestnut, larch, rubber trees, and fruit trees [27]. Reports have not, however, associated increased severity of Armillaria with an increased number of rhizomorphs, which could have occurred in moist conditions. The present results from the Oder Valley show that periodic flooding may decrease the number of $A$. gallica rhizomorphs in soil. Significantly fewer soil rhizomorphs were collected from flooded sites than from the non-flooded site. This is in accordance with the general behaviour of the wood-decaying Basidiomycota, which grow more slowly at higher water content.

Fewer rhizomorphs in moist soil may be attributed to the dependence of rhizomorphs on an adequate supply of oxygen. Aeration is an important factor governing rhizomorph formation and extension. A submerged Armillaria thallus produces mycelium, but rhizomorphs only in certain, moderately aerated conditions. Optimal growth of rhizomorphs occur where oxygen level is high at the apex and at moderate concentration externally. It should also be mentioned that flooding not only affects the concentration of oxygen but also increases the concentration of toxic products of respiration in less aerobic conditions.

Previous reports on the effects of moisture on rhizomorph formation are contradictory. Armillaria rhizomorphs have been reported from mine and water work tunnels. Rhizomorphs of A. gallica were shown to grow better in moist places in the Ozark Mountains in the USA $[23,24]$. These would suggest high moisture preferences of Armillaria. Low sensitivity of A. gallica to moisture in its formation of rhizomorphs has also been reported, however [28]. The present results confirm another recent report [29] that rhizomorph length was negatively correlated with volumetric water content (VWC); rhizomorphs grew most rapidly with low VWC $(<1 \%)$. Flooding can, 
however, still be considered to be a short-term inciter and stress inducer occurring between "primary" factors and "secondary" agents, predisposing the tree to infection.

The pathological potential of species of Armillaria is not completely clear. It seems justified to consider even the pathogenic species to be "opportunistic and secondary" (requiring stress-induced predisposition of the host tree) rather than as "non-opportunistic and primary pathogens." Armillaria gallica has been considered to be an opportunistic pathogen with a low level of aggressiveness and inability to colonize vigorously growing hosts [30]. In sites where A. solidipes accompanies A. gallica, the former plays a more significant role in the decline of oaks. However, despite making a very late contribution to the disease process, A. gallica was actively involved in the decline of 20-year-old oaks following defoliation [22]. Also, it has been found that all trees harbouring A. gallica died, suggesting earlier successful infection followed by death [24]. This fungus has been considered to be one of the primary disturbance agents in temperate, mixed oak forests [31, 32]. In Wołów, Armillaria disease seems to be stress-related and "secondary." The future of colonized and non-colonized trees will depend on soil moisture. Those trees not infected by Armillaria may recover in the later absence of this stress factor, while those infected may suffer.

While other Armillaria species depend more on rootto-root contact for the spread of mycelia and colonization of plants, A. gallica depends more on penetration of roots by rhizomorphs [33]. Armillaria gallica generally prefers warmer sites. Its hyphal growth is greater at higher temperatures [34], and so the growth of rhizomorphs may be generally favoured by the mild winters and warm summers of Lower Silesia. Rhizomorphs can completely cover roots of healthy trees and may: i) infect when conditions become suitable and ii) help the fungus to compete with other fungi for resources. Thus, the fungus may reduce the activity of other more virulent Armillaria species [23]. When A. solidipes and A. gallica co-occur in the same forest, infection of root systems by $A$. gallica may reduce damage or prevent infection by $A$. solidipes [35]. Successful competition may be the reason that other Armillaria species were rarely detected in Wołów. Armillaria cepistipes and A. borealis, which occurred rarely in this or other studies [21], are weak plant pathogens. The former is considered to be the least dangerous pathogen among all Armillaria species. These two species are almost completely indistinguishable from each other in behaviour and appearance. Armillaria cepistipes (on beech), occurring most frequent at elevations above 600 $\mathrm{m}$, is considered to be a mountain species, while A. gallica (on oak, in alluvial forests) is a lowland species. Despite their differences in ecological preferences, they can occur sympatrically [11].

Armillaria borealis was found at two sites in Wołów. This is the first record of $A$. borealis in southern Poland. So far the species had been recorded from northern and central parts of Poland (at least $300 \mathrm{~km}$ apart, between 53 $70^{\prime}$ and $52^{\circ} \mathrm{N}$ and $18^{\circ} 10^{\prime}$ and $22^{\circ} 50^{\prime} \mathrm{E}$ ) [36]. However, this species is not restricted to northern Europe, having been recorded also in more southern latitudes in Europe [37].

Armillaria rhizomorphs were absent from two sites (6 and 9), and occurred at greatest density at flooded site 2 in amounts comparable with the non-flooded control. Sites 6 and 9 were covered by younger trees less than 50 years old, but with soil habitat similar to that at other sites. They were, however, located very close to the river (500 and $270 \mathrm{~m}$ ). Site 2 was located $850 \mathrm{~m}$ from the river and was partly surrounded by a tall soil embankment that could have limited the amount and duration of flooding. When results from this unusual site are excluded from the calculations, the mean number of rhizomorphs from sites flooded twice (3.5) is similar to that from sites flooded only once (3.0). Differences in rhizomorph density in locations close to each other suggest that the rhizomorph network of A. gallica has large spatial and temporal variability, which may result from changes in the environment and occur quickly [38].

Restriction fragment length polymorphisms (RFLP) of the IGS-1 rDNA were used here for Armillaria identification. This region has been used successfully for distinguishing most species in other studies on Armillaria [16, 17, 39-43]. The restriction enzyme TagI, used in this study, has rarely been used previously and its patterns are not well known [17]. Armillaria cepistipes gave a rare pattern with AluI (410 240 190), which was known previously only from Japanese isolates of this fungus [14]. The similarity of patterns for $A$. borealis and A. solidipes using $A l u \mathrm{I}$ and $T a q \mathrm{I}$ necessitated the use of an additional functionally efficient enzyme, BsmI.

Studies on population genetics have shown that A. gallica genets grow mitotically from a single point of origin and eventually occupy territories that include many adjacent root systems over large areas (several hectares) of forest floor. A single genet was found to occupy at least 15 ha in northern Michigan, with an estimated age of more than 1,500 years. Based on the low mutation rates observed in large, long-lived individuals, A. gallica should have an especially stable genome and genetic stability [44]. In the present study, however, four AluI, two TaqI, and seven MspI patterns were obtained for A. gallica, which indicate relatively high polymorphism in its IGS-1 rDNA. This suggests that the mixed oak forest landscape in Lower Silesia is composed of numerous $A$. gallica genets and each occupies a relatively small area. The existence of possible ecologically relevant genetic variation within vegetative individuals of $A$. gallica at smaller or broader geographic scales has been observed previously $[45,46]$. This suggests that a process similar to evolutionary adaptation can take place within the soma of a genetic individual of the fungus. Armillaria gallica was reported to possess among-cell genetic variation for response to changes in environmental variables, i.e., $\mathrm{pH}$, temperature, and water potential [45]. Differences in cellline genotypes cause differences in rates of growth and reproduction. Genotypes have potential for local change of allele frequencies that allow dynamic mycelial boundaries to re-configure themselves in response to local conditions. 
In this scenario, genetic mosaicism in association with selection may produce genetically different individuals.

Genetic diversity in soil-borne fungi is strongly related to climatic factors, mostly temperature and precipitation. Both influence the frequency and abundance of sporulation. High genotypic variation in populations of $A$. gallica may result from the mild climate in Lower Silesia. A long period of vegetation stimulates the production of fruit bodies and formation of new genets, and increases the competition between genets. The annual precipitation in this region is not high $(612 \mathrm{~mm})$. The rainfall occurs, however, mostly in August-October, when mild temperatures persist and annual fungi are most likely to fruit and basidiospores to spread. Effects of periodic flooding on interspecies variation cannot be discounted. Wetter forest types caused greater species diversity in Armillaria in eastern states of the USA [32].

\section{Conclusions}

These results, and comparison with those from other Armillaria population studies, suggest that flooding tends to decrease the abundance of soil rhizomorphs but does not affect the diversity of Armillaria species. The decreased abundance of Armillaria rhizomorphs in soil subjected to flooding may be part of the general loss of fungi that is associated with flooded soil syndrome. Flooding may still be considered, however, to be a short-term inciter and stress inducer, occurring between "primary" factors and "secondary" agents that predispose the tree to infection.

\section{Acknowledgements}

This paper covers part of the research conducted within the task financed by the National Science Centre no. NN309712140, entitled Ecological conditions determining health of oak stands affected by flood.

\section{References}

1. CEITEL J. Lasy dębowe w Polsce. In: Bugała W. (Ed.) Dęby, Institute of Dendrology, PAN, Poznań-Kórnik, 114, 2006 [In Polish].

2. MAŁECKA M. Krótkoterminowa prognoza występowania ważniejszych szkodników i chorób infekcyjnych drzew leśnych w Polsce w 2015 roku (Short-term prognosis of occurrence of the important pests and diseases of trees in Poland in 2015). Instytut Badawczy Leśnictwa, 31, 2015 [In Polish].

3. KWAŚNA H., SZEWCZYK W., BEHNKE-BOROWCZYK J. Gatunki Phytophthora i Pythium w korzeniach i glebie dębu szypułkowego na terenach popowodziowych w Nadleśnictwie Wołów. (Species of Phytophthora and Pythium in roots and soil of the pedunculate oaks in periodically flooded areas in Wołów Forest District). Sylwan 159 (7), 531, 2015 [In Polish].

4. BEATRIZ IBÁÑEZ B., GÓMEZ-APARICIO L., STOLL P., ÁVILA J.M., PÉREZ-RAMOS I.M., MARAÑÓN T. A Neighborhood Analysis of the Consequences of Quercus suber Decline for Regeneration Dynamics in Mediterranean Forests. PLoS One. 10 (2), e0117827, 2015.

5. ANONYMOUS. The habitats directive. 2015. http:// ec.europa.eu/environment/nature/legislation/habitatsdirective/index en.htm

6. KIM M.S., KLOPFENSTEIN N.B., MCDONALD G.I. Effects of forest management practices and environment on occurrence of Armillaria Species. Jour. Korean For. Soc. 99 (2), 251, 2010.

7. ŻÓŁCIAK A. Armillaria species in coniferous stands. Acta Mycol. 42 (2), 211, 2007.

8. SZEWCZYK W., ŁAKOMY P. The occurrence of Armillaria species in Siemianice Experimental Forest District. Acta Sci. Pol. Silv. Colendar. Rat. Ind. Lignar. 10 (1), 5, 2011.

9. SZEWCZYK W., KWAŚNA H., BOCIANOWSKI J., BEHNKE-BOROWCZYK J., RATAJCZAK A., ŚWIETLIK A. Diversity of Armillaria ostoyae in Scots pine plantations in Poland. Dendrobiology 72, 125, 2014.

10. ŻÓŁCIAK A. Opieńki (Armillaria). CILP. Warszawa, 2005 [In Polish].

11. ANTONÍN V., TOMŠOVSKY M., SEDLÁK P., MAJEK T., JANKOWSKI L. Morphological and molecular characterization of the Armillaria cepistipes - A. gallica complex in the Czech Republic and Slovakia. Mycol. Progress 8, 259, 2009.

12. BORECKI T., KECZYŃSKI A. Atlas ubytku aparatu asymilacyjnego drzew leśnych (Atlas of assimilation apparatus loss in forest trees). Agen. ATUT Warszawa, 1992 [In Polish].

13. WYRZYKOWSKI S., ZAJĄCZKOWSKI S. Wskazówki metodyczne w sprawie sporządzania ocen stanu lasu (Methodical hints referring to forest conditions evaluation). PIOŚ Bibl. Monit. Środ. Warszawa, 1995 [In Polish].

14. NEI M., LI W.H. Mathematical model for studying genetic variation in terms of restriction endonucleases. Proceedings of the National Academy of Sciences of the United States of America 76, 5269, 1979.

15. HARRINGTON T.C., WINGFIELD B.D. A PCR-based identification method for species of Armillaria. Mycologia 87, 280, 1995.

16. PÉREZ SIERRA A., WHITEHEAD D.S., WHITEHEAD M.P. Investigation of a PCR-based method for the routine identification of British Armillaria species. Mycol. Res. 103 (12), 1631, 1999.

17. MATSUSHITA N., SUZUKI K. Identification of Armillaria species in Japan using PCR-RFLP analysis of rDNA intergenic spacer region and comparisons of Armillaria species in the world. J. For. Res. 10, 173, 2005.

18. HOUSTON D.R. A host-stress-saprogen model for forest dieback-decline diseases. In: Manion P.D. and Lachance D. (Eds.) Forest Decline Concepts, American Phytopathological Society, St Paul, MN, 1, 1992.

19. DOBROWOLSKA D. Effect of stand density on oak regeneration in flood plain forests in Lower Silesia, Poland. Forestry 81 (4), 511, 2008.

20. SZEWCZYK W., KUŹMIŃSKI R., MAŃKA M., KWAŚNA H., ŁAKOMY P., BARANOWSKA-WASILEWSKA M., BEHNKE-BOROWCZYK J. Występowanie Erysiphe alphitoides $\mathrm{w}$ drzewostanach dębowych dotkniętych klęską powodzi (Occurence of Erysiphe alphitoides in oak stands affected by flood). Leśne Prace Badawcze 76 (1), 73, 2015 [In Polish].

21. ŁAKOMY P., SIWECKI R. Grzyby z rodzaju Armillaria występujące w Nadleśnictwie Smolarz (Armillaria species occurences in Smolarz Forest District). Sylwan 4, 115, 2000 [In Polish]. 
22. MARÇAIS B., BRÉDAN. Role of an opportunistic pathogen in the decline of stressed oak trees. J. Ecol. 94, 1214, 2006.

23. BRUHN N.J., WETTEROFF J.J., MIHAIL J.D., KABRICK J.M., PICHENS J.B. Distribution of Armillaria species in upland Ozark Mountain forests with respect to site, overstory, species composition and oak decline. Eur. J. For. Path. 30, 43, 2000.

24. KELLEY M.B., FIERKE M.K., STEPHEN F.M. Identification and distribution of Armillaria species associated with an oak decline event in the Arkansas Ozarks. For. Path. 39 (6), 397, 2009.

25. BAUMGARTNER K., RIZZO D. M. Ecology of Armillaria spp. in mixed-hardwood forests of California. Plant Dis. 85, 947, 2001.

26. MCLAUGHLIN J. A. Distribution, hosts, and site relationships of Armillaria spp. in central and southern Ontario. Can. J. For. Res. 31, 1481, 2001.

27. FOX R.T.V. Biology and life cycle. In: Fox R.T.V. (Ed.). Armillaria root rot: Biology and control of honey fungus. Andover, England, Intercept Limited. 3, 2000.

28. MIHAIL J.D., BRUHN J.N., LEININGER T.D. The effects of moisture and oxygen availability on rhizomorph generation by Armillaria tabescens in comparison with A. gallica and A. mellea. Mycol. Res. 106 (6), 697, 2002.

29. VARGAS R., ALLEN M.F. Dynamics of fine root, fungal rhizomorphs, and soil respiration in a mixed temperate forest: Integrating sensors and observations. Vadose Zone Journal, 7, 1055, 2015.

30. WARGO P.M., HARRINGTON T.C.. Host stress and susceptibility. In: Shaw C.G. and Kile G.A. (Eds.) Armillaria Root Disease. Washington, D.C., Forest Service United States Department of Agriculture, 88, 1991.

31. BRAZEE N.J., WICK R.L. Armillaria species distribution on symptomatic hosts in northern hardwood and mixed oak forests in western Massachusetts. For. Ecol. Manage. 258, 1605, 2009.

32. BRAZEE N.J., MARRA R.E., WICK R.L. Genotypic diversity of Armillaria gallica from mixed oak forests in Massachusetts . Mycologia 104 (1), 53, 2012.

33. BRUHN J.N., MIHAIL J.D. Opportunistically pathogenic root rot fungi: Armillaria species. In: Hanson P.J. and Wullschleger S. (Eds.) North American deciduous forest responses to changing precipitation regimes. New York, Springer-Verlag Inc, 337, 2003.

34. RIND B., LOSEL D.M. Effect of nutrients and temperature on the growth of Armillaria mellea and other fungi. Indus. J. Biol. Sci. 2, 326, 2005
35. ANONYMOUS. Armillaria gallica. Insects and Diseases of Canadian Forests. Canadian Forest Service, 2011.

36. ŻÓŁCIAK A. Rozmieszczenie grzybów z rodzaju Armillaria w Polsce oraz ich rośliny żywicielskie. (Distribution of the Armillaria species and their host plants in Poland) Prace Inst. Bad. Leśn., ser. A, 956, 7, 2003 [In Polish].

37. LUSHAJ B.M., WOODWARD S., KEČA N., INTINI M. Distribution, ecology and host range of Armillaria species in Albania. For. Path., 40 (6), 485, 2010.

38. LAMOUR A., TERMORSHUIZEN A.J., VOLKER D., JEGER M.J. Network formation by rhizomorphs of Armillaria lutea in natural soil: their description and ecological significance. FEMS Microb. Ecol. 62 (2), 222, 2007.

39. KEČAN., BODLES W.J.A., WOODWARD S., KARADZIC D., BOJOVIC S. Molecular-based identification and phylogeny of Armillaria species from Serbia and Montenegro For. Path. 36, 41, 2006.

40. FUKUDA M., NAKASHIMA E., HAYASHI K., NAGASAWA E. Identification of the biological species of Armillaria associated with Wynnea and Entoloma abortivum using PCR-RFLP analysis of the intergenic region (IGR) of ribosomal DNA. Mycol. Res. 107, 1435, 2003.

41. HASEGAWA E., OTA Y., HATTORI T., KIKUCHI T. Sequence-based identification of Japanese Armillaria species using the elongation factor-1 alpha gene. Mycologia, 102 (4), 898, 2010.

42. SCHNABEL G., ASH J.S., BRYSON P.K. Identification and characterizationof Armillaria tabescens from the southeastern United States. Mycol. Res. 109, 1208, 2005.

43. SEKIZAKI H., KUNINAGA S., YAMAMOTO M., ASAZU S.N., SAWA S., KOJOMA M., YOKOSAWA R., YOSHIDA N. Identification of Armillaria nabsnona in gastrodia tubers. See comment in PubMed Commons below. Biol. Pharm. Bull. 31 (7), 1410, 2008.

44. GLADFELTER A., BERMAN J. Dancing genomes: fungal nuclear positioning. Nat. Rev. Microbiol. 7 (12), 875, 2009.

45. PEABODY R.B., PEABODY D.C., TYRRELL M.G., EDENBURN-MCQUEEN E., HOWDY R.P., SEMELRATH K.M. Haploid vegetative mycelia of Armillaria gallica show among-cell-line variation for growth and phenotypic plasticity. Mycologia 97 (4), 777, 2005.

46. GATTO A., SICOLI G., LUISI N. Genetic diversity within an Italian population of forest Armillaria gallica isolates as assessed by RAPD-PCR Analysis. J. Phytopathol. 157 (2), 94, 2008. 